\title{
大規模災害時におけるリハビリテーション医療の役割*1
}

\author{
水尻強志*2
}

\section{The Role of Rehabilitation Medicine in Large-scale Disasters*1}

\author{
Tsuyoshi MIzushiri ${ }^{* 2}$
}

\begin{abstract}
In recent decades, natural disasters have increased markedly. A large-scale disaster can cause not only severe injuries but also stress-related diseases such as cardiovascular events. Particularly, the elderly and persons with preexisting disabilities are at greater risk for injuries, worsening disabilities and deaths in a disaster. The Great East Japan Earthquake 2011 revealed that rehabilitation medicine had some essential roles for people requiring assistance in a largescale disaster. Firstly, in the acute phase immediately after the disaster, it was important to protect elderly and disabled people from dangerous situations. In this instance, even though significant numbers of vulnerable people requiring assistance remained in the affected area, there were insufficient sheltered locations available, because a large number of medical and welfare facilities were destroyed. Secondly, in the post acute phase after the earthquake, the medical rehabilitation needs for disaster-related disease such as cerebrovascular accidents increased. Finally, in the chronic phase of the disaster, the community based rehabilitation needs to prevent deconditioning syndrome had gradually grown. The aging of the Japanese population is a crucial issue. In this regard, disaster rehabilitation for vulnerable people is similar to comprehensive community care in many aspects. To support disaster victims, the Disaster Acute Rehabilitation Team (DART) and the Japan Rehabilitation Assistance Team (JRAT) have been proposed to take the lead in disaster rehabilitation. To support these and other ongoing efforts and to better prepare for the future, the Japanese Association of Rehabilitation Medicine and other related rehabilitation professional societies should provide specialized training on disaster rehabilitation. (Jpn J Rehabil Med $2015 ; 52: 207-211)$
\end{abstract}

Key words : 東日本大震災 (the Great East Japan Earthquake), 災害リハビリテーション (disaster rehabilitation), 災害弱者 (people requiring assistance during a disaster), 災害関 連疾患 (disaster-related diseases), 低活動状態 (deconditioning)

\section{はじめに}

世界的に見て，大規模災害が顕著に増加している。 自然災害は，1980 1989 年比で $2000 〜 2009$ 年は 3 倍増となっている，特に，地球温暖化の影響で暴風雨 や水害による被害が増えている1 .

このような状況のなか, 自然災害後の緊急的リハビ

\section{リテーション（以下，リハ) 介入が課題であるという}

認識が高まり，The International Society of Physical and Rehabilitation Medicine（ISPRM）の第 5 回世界 会議（Istanbul，2009 年）の場で議論がなされた。 そ の後にまとめられた報告では, リハが必要な外傷は, 災害の種類や規模によって大きく異なっており，長骨 骨折, 四肢切断, 脊䯣損傷, 頭部外傷, 未梢神経障害

2015 年 1 月 12 日受稿

${ }^{* 1}$ 本稿は第 51 回日本リハビリテーション医学会学術集会教育講演（2014 年 6 月 7 日, 名古屋）をまとめたものである.

*2 宮城厚生協会長町病院リハビリテーション科/ T 982-0011 宮城県仙台市太白区長町 3 丁目 7-26

Department of Rehabilitation Medicine, Miyagi Kousei Kyokai Nagamachi Hospital

E-mail : tmzsr@zmkk.org 
などが含まれていることがわかった。また，災害以前 から障害を持っている者は，慢性障害の悪化だけでな く，外傷や死亡のリスクが高いことも示された ${ }^{2)}$.

日本では，阪神淡路大震災の教訓をふまえ，救命・ 救護を目的としたDisaster Medical Assistance Team （DMAT）が制度化されている。DMATは，多発外 傷, クラッシュ症候群など外傷系傷病者への救命救急 対応が主な任務であり，リ八医療としても，外傷系患 者への対応に急性期から関わることが望ましい。一 方， 4 人に 1 人が 65 歳以上という高齢社会に突入す る時代背景を考えると，災害弱者に対する援助という 立場で災害時リ八を論議することも重要となっている。

当院は，東日本大震災被災県にあるリ八医療機関と して災害弱者への支援を行った ${ }^{3)}$ 。この経験をふま 元，避難行動要支援者一の援助，災害関連疾患への対 応，低活動状態による生活機能低下への備えという 3 つの視点で大規模災害時におけるリ八医療の役割につ いて本稿をまとめた。

\section{災害弱者への支援とリハ医療の役割}

\section{1. 避難行動要支援者への援助}

東日本大震災リ八支援 10 団体が企画・編集した「大 規模災害リハビリテーション対応マニュアル」4) で は，被災地の状況変化を，被災混乱期，応急修復期， 復旧期, 復興期のフェーズに分けている。被災混乱期 （発災直後〜約 72 時間）には，DMATを中心とした 医療支援に加え，災害弱者への対応が問題となる。

新潟中越地震捛よびその後に相次いだ風水害におい て高齢者の犠牲が多かったことを鑑み，国は「災害時 要援護者の避難支援ガイドライン」（2006 年 3 月作 成 $)^{5)}$ を示し，市町村にその取組みを周知してきた。 しかし，2011年に起こった東日本大震災においては， 被災地全体の死者数のうち 65 歳以上の高齢者の死者数 は約 6 割と多く，障害者の死亡率は被災住民全体の死亡 率の約 2 倍に上った。この反省をふまえ，新たに「避難 行動要支援者の避難行動支援に関する取組指針」(2013 年 8 月改定 $)^{6)}$ を国は作成し，避難行動要支援者名簿の 作成, 福祉避難所指定とその運営についての強化など の対策を方針として揭げた．表 1 に，「宮城県避難行動 要支援者等に対する支援ガイドライン」7)に例示された 具体的避難行動要支援者例を示す。要介護高齢者，身 体障害者など，リ八医療対象者が多数含まれている.

しかし，東日本大震災時では，福祉避難所だけで災
害弱者の保護をすることは実際には困難であり，医療 機関も含めた地域連携が求められた，居宅からの移動 だけでなく，被災した医療機関や介護施設などからの 要援護者移動が発生した。特に，常時特別な医療を必 要とする在宅療養者は, 最初から医療機関で保護する 必要があった。多くの在宅酸素の患者も来院し数日滞 在した ${ }^{3,8}$.

大規模災害時には，災害弱者の移送の問題が発生す る。移送には，施設内移動，居宅等からの移動，施設 間移動の 3 種類がある。当院では，2011 年 3 月 11 日 の東日本大震災発生直後, 病棟の一部が使用できなく なったため，1階外来スペースに患者を移送した（施 設内移動)。また，在宅酸素療法中の方なども電気が 使えないために病院に避難してきた（居宅等からの移 動). 3 月 18 日からは, リ八室の一部を「災害時救急」 スペースと命名し，他医療機関からの患者受け入れ機 能を強化した (施設間移動 $)^{9)}$.

施設間移動が必要となった要因として, 東日本大震 災時には, 岩手, 宮城, 福島 3 県の病院 380 施設中, 全壊 11 施設，一部損壊 289 施設あわせて 300 施設 $78.9 \%$ が被災したことが挙げられる．沿岸部に限る と，ほぼ全ての医療機関が機能の全部ないし一部を失っ てしまった。職員出勤, 医薬品確保も困難だった。しか も，情報手段が失われ，各医療機関の現状がリアルタイ ムに把握できなかった。被災地の回復期リ八病棟でも， 甚大な被害を受け病棟機能を失ったところがあった ${ }^{9}$.

2012 年に米国東海岸をハリケーンサンディが襲っ た時にも，同様に多くの医療機関が被災した。急性期

表 1 具体的な避難行動要介護者 (文献 7 をとに作成)

1. 高齢者 (要介護認定者, 一人暮らし高齢者 (高齢者 のみの世帯), 家族と同居しているものの一日のう ち一定時間以上一人になることが多い高齢者, 寝た きり高齢者，認知症高齢者など)）

2. 身体障害者 (視覚障害者, 聴覚障害者, 肢体不自由 者, 内部障害者など)

3. 知的障害者

4. 精神障害者

5. 高次脳機能障害者

6. 発達障害者

7. 常時特別な医療等を必要とする在宅療養者（人工透 析を受けている者, 医療機器等を装着している者, 酸素吸入が必要な者など)

8. 市町村の生活支援を受けている難病患者

9. 乳幼児 $\cdot$ 児童 $($ 特に低学年児童)

10. 妊産婦 
表 2 震災関連死の原因区分別状況（複数選択）

\begin{tabular}{llrrr}
\hline & & $\begin{array}{c}\text { 岩手県及び } \\
\text { 宮城県 }\end{array}$ & 福島県 & 合計 \\
\hline $1-1$ & 病院の機能停止による初期治療の遅れ & 39 & 51 & 90 \\
$1-2$ & 病院の機能停止 (転院を合む) による既往症の増悪 & 97 & 186 & 283 \\
$1-3$ & 交通事情等による初期治療の遅れ & 13 & 4 & 17 \\
2 & 避難所等への移動中の肉体・精神的疲労 & 21 & 380 & 401 \\
3 & 避難所等における生活の肉体・精神的疲労 & 205 & 433 & 638 \\
$4-1$ & 地震・津波のストレスによる肉体・精神的疲労 & 112 & 38 & 150 \\
$4-2$ & 原発事故のストレスによる肉体・精神的疲労 & 1 & 33 & 34 \\
$5-1$ & 救助・救護活動等の激務 & 1 & & 1 \\
$5-2$ & 多量の塵灰の吸引 & 110 & 105 & 215 \\
$6-1$ & その他 & 65 & 56 & 121 \\
$6-2$ & 不明 & 664 & 1286 & 1950 \\
\hline & 合計 & & & \\
\hline
\end{tabular}

震災関連死死者数等について ${ }^{13)}$ ，「東日本大震災に打ける震災関連死に関する原因等（基礎的 数值)」について」(平成 24 年 8 月 21 日, 復興庁) より引用

病床が不足し，後方医療機関への移送が必要となる， 透析患者のニーズが高まるなどの課題が浮き彫りと なった ${ }^{10,11)}$.

大規模災害時には，通常とは異なる様々な課題が被 災を免れた医療機関にのしかかる。災害医療は決して 急性期医療を行っている大規模病院だけの課題ではな い. 保健医療福祉複合体として, リ八医療や介護事業 を積極的に展開している中小病院にも，不足する急性 期病院の後方病床や居宅等からの避難行動要支援者の 受入れという重要な役割がある。

\section{2. 災害関連疾患への対応}

応急修復期〜復旧期（概ね 6 力月まで）には，災害 関連疾患に注目する必要がある。

大地震時には, 環境の激変に伴う震災関連死が発生 する ${ }^{12)}$. 復興庁は，東日本大震災時の震災関連死の死 者等についての調查を実施している ${ }^{13)}$. 表 2 に, 震災 関連死の原因区分別状況を示す。選難所等における, ないし, 避難所への移動中における生活の肉体・精神 的疲労が最も多い. 地震・津波のストレス，原発事故 のストレスも原因として重要である．病院の機能停止 による初期治療の遅れや既往症の増悪も問題となる.

大規模災害時には，心血管イベント患者が増加する ことが知られている. 苅尾は, 総説のなかで, その機 序として，震災時に生じた恐怖やその後の環境変化に 伴う極めて強い精神心理ストレスや，睡眠障害による 心血管リスク因子の増悪を指摘している。そして, 1）脳卒中，心筋梗塞が増加する，2）被害状況と比例
する，3）災害後 $2 \sim 3$ 力月持続する，4）高齢者に多 い，5）夜間発症が多い（次に多いのは早朝）という 特徵があることを述べている ${ }^{14)}$.

Sokejima らは，阪神淡路大震災（1995 年）におけ る淡路島 2 町の国保デー夕を用いた研究では, 震度が 強い地域ほど脳卒中発症が増加したと報告してい $る^{15)}$. Tsuchida らは, 能登半島地震（2007 年）にお ける研究で, 前年と比し, 急性冠症候群, 脳出血の搬 送が増えたと記載している ${ }^{16)}$ 。また，新潟中越地震 （2004 年）において，Nakagawa らは心筋梗塞死が増 えたと述べており ${ }^{17)}$ ，Sato らはたこつぼ型心筋症発症 が増加したと報告している ${ }^{18)}$.

Aoki らは，東日本大震災に抄ける心血管疾患と肺 炎の現状を，宮城県における救急車搬送時記録をもと に調査した。その結果，心不全，急性冠症候群，脳卒 中，心肺停止，肺炎いずれも地震後に増加したことが わかった。宮城県では, 震災後, 多くの人が避難所で 過ごし, 生活必需物質, 水道・電気, 医薬品の不足を 余儀なくされた。さらに, 頻回の余震, 低温が状沉を 悪化させた。このような状況のなか，人びとは極度の 身体的精神的ストレスを生じ，交感神経系が充進した ことによる心血管疾患を起こしたおそれがあると述べ ている ${ }^{19)}$.

当院で, 2011 年 3 月 12 日以降の 5 カ月間にリ八処 方を行った入院患者 224 名を調べたところ，震災関連 疾患疑いを 48 名 $21.4 \%$ に認めた。廃用症候群（肺炎・ 低体温等） 23 名，脳卒中 17 名，骨折 8 名だった。当 
初は廃用症候群患者が多かったが，その後脳卒中患者 に対象が移行した ${ }^{20)}$ ．当院が経験した代表的震災関連 疾患事例を表 3 に示す。

リハが必要となる災害関連疾患がどの程度増加する かを示した系統的な研究はない．しかし，心血管イ心゙ ントが増大するという研究結果をふまえると，リ八医 療の立場から災害関連疾患へアプローチを強化するこ とは必要である。

\section{3. 低活動状態による生活機能低下（廃用症候群） の予防}

低活動状態による生活機能低下（廃用症候群）にも 注意する必要がある，避難所や仮設住宅暮らしのなか で，生活全体が不活発になり，生活機能が低下する。 東日本大震災では，もともと少なかった医療機関や介 護事業所の被災による援助機能低下がより被害を広げ ており，復興期（6 カ月以降）も続いている.

大川は，今後の災害医療の新しい課題として，「防 げたはずの生活機能低下」予防の重要性を強調し，災 害時には生活不活発病による生活機能低下が同時多発 する。災害時の生活機能低下への取り組みの不十分さ は，平常時の取り組みの不十分さの反映と考えるべき であると述べている ${ }^{21)}$.

成田は，東日本大震災の特徵を，辺境・高齢化・医 療過疎といった脆弱地域に広域に生じた複合災害とま とめている。阪神淡路大震災時（1995 年）の兵庫県 の高齢化率は $12.9 \%$ たったのに対し，東日本大震災 時（2011 年）の気仙沼の高齢化率は $30 \%$ に達してい る. 高齢者を支える医療機関，介護事業所などの機能 復旧の遅れが避難者の廃用症候群および生活不活発病 の要因として重要であり，仮設住宅に経済的・身体的 弱者が残っていることを考えると，回復期リ八病棟開 設を含め, リ八提供体制構築が大きな課題であると強 調している ${ }^{22)}$.

冨山は，東日本大震災時の経験として，災害急性期 から要援護者には支援が必要であることを自覚し，避 難所へのリハ支援を継続的に実施したことを報告して いる。ささらに，災害医療の慢性期にあたる時期におい ても，仮設住宅入居者を対象とした活動を継続してい る。リハ機能が充実していたことが，多彩な活動の裏 づけとなっている

被災地では，リ八支援活動が継続して行われてい る.当院でも，近隣の仮設住宅への支援を継続してい る。しかし，被災した地域のほとんどがリ八過疎地域
表 3 当院における震災関連疾患の代表的事例

$<$ 脳卒中 $>$

·70歳代女性：自宅が全壊し，家族宅に身を寄せていた。 $3 / 24$, 心原性脳塞栓発症し, 急性期病院入院. 以前は 認めなかった心房細動があった. $5 / 12$, 当院転院.

・80 歳代女性：津波被災後, 避難所暮らしをしていた。 ペースメーカー植込み後でワーファリンコントロール 中だった。身体ひとつで避難した。1 週間経ってから 家族がかかりつけ医院に薬をとりに行った，3/26，心 原性脳塞栓発症 $L$, 急性期病院入院. $5 / 20$, 当院転院.

・70 歳代女性：石巻在住. 津波被災後体育館の避難所で 生活していた. $5 / 2$, 脳梗塞発症. 地元の病院を経て, 仙台市内の急性期病院に転送された。たこつぼ型心筋 症, うっ血性心不全を合併. 出血性梗塞となり，5/ 17 , 開頭血腫除去術を施行. $6 / 27$, 当院に転院. $<$ 廃用症候群 $>$

- 55 歳男性：慢性期䅡髄損傷. 独居. 震災時, 津波をの がれ近くの急性期病院に避難したが, ライフライン途 絶のため低体温となった. $3 / 17$, 当院転院.

であり，低活動に伴う生活機能低下への取組みは全体 として不十分であることは否めない.

\section{大規模災害に対する備え}

医療機関として最も大事なことは，大規模災害に あっても，自らの役割を発揮できるように備えをして おくことである。地域り八医療を熱心に行っている医 療機関では，災害拠点病院の機能維持を図るための後 方支援，災害弱者の保護，災害関連疾患や低活動状態 による生活機能低下への対策が求められる．大規模災 害への対策と都市部の急速な高齢化対策の類似性に注 目し，地域包括ケアのなかに位置づけを明確にし，準 備を進めることが求められる.

一方，支援にあたっては，被災地医療機関の側面援 助と同時に，精神的支援や燃え尽き症候群予防に配慮 する必要がある，大規模災害リ八対応マニュアルで は，Disaster Acute Rehabilitation Team (DART)，Japan Rehabilitation Assistance Team（JRAT）の整備を 提案している ${ }^{4}$. DART は，ISPRM が提案した概念で あり，被災混乱期にDMAT とともに初動時の対応を することを想定されている ${ }^{2}$ 。一方，JRAT は応急修 復期以降の対応が任務と位置づけられている．両者の 位置づけを明確にし，研修を進めることが求められて いる。

石井は，長期間の支援に扔いては，担当部署・地域 を決め，継続して支援できる体制を整備することが求 められると述べている ${ }^{23)}$ 。情報を共有しながら，自律 
的に活動できることが現地の負担軽減に通じる. JRATの支援においては，医師，看護師・介護福祉士・ リハスタッフなどによる複数名のチームで, リハ病棟 や避難所を長期間担当するといったイメージを描くこ とが望まれる，支援にあたっては，被楽地医療機関の 自立性を尊重した側面援助と同時に，精神的支援や燃 え尽き症候群予防に配慮することが求められる。

\section{おわりに}

東日本大震災を契機とし，大規模災害に対し，どの ように備えるかという意識が高まっている.

医療機関として最も大事なことは，大規模災害に あっても，自らの役割を発揮できるように備えをして おくことである.リハ医療を熱心に行っている医療機 関としては，災害拠点病院の機能維持を図るための後 方支援，災害弱者の保護，災害関連疾患や生活不活発 病への対策が求められる. 大規模災害への対策と都市 部の急速な高齢化対策の類似性に注目し，準備を進め ることが実際的である.

災害時リハ支援を行うために，DARTやJRAT の整 備が提案されている. 日本リ八医学会として, 組織的 な研修を行うことが望まれる。

\section{文献}

1) Leaning J, Guha-Sapir D : Natural disasters, armed conflict, and public health. N Engl J Med 2013 ; 369 : 18361842

2) Rathore FA, Gosney JE, Reinhardt JD, Haig AJ, Li J, DeLisa JA : Medical rehabilitation after natural disasters : Why, When, and How? Arch Phys Med Rehabil 2012 ; $93: 1875-1881$

3) 水尻強志: 東日本大震災において再認識したリハビリ テーションの役割. J Clin Rehabil 2011；20 : 964-965

4）東日本大震災リハビリテーション支援関連 10 団体『大 規模災害リハビリテーション対応マニュアル』作成 ワーキンググループ 編: 大規模災害リハビリテーショ ンマニュアル. 医歯薬出版, 東京, 2012

5）災害時要援護者の避難支援ガイドライン. Available from URL : http://www.bousai.go.jp/taisaku/youengo/ 060328/pdf/hinanguide.pdf (2015 年 1 月 12 日引用)

6）避難行動要支援者の避難行動支援に関する取組指針. Available from URL : http://www.bousai.go.jp/taisaku/ hisaisyagyousei/youengosya/h25/pdf/hinansien-hon. $\operatorname{pdf}$ (2015 年 1 月 12 日引用)

7）宮城県避難行動要支援者等に対する支援ガイドライン. Available from URL : http://www.pref.miyagi.jp/soshiki/ hohusom/guideline.html (2015 年 1 月 12 日引用)

8）冨山陽介: 被災地のリハビリテーション一東日本大震 災で損傷を免れた病院として : 宮城県一. Jpn J Rehabil
Med 2011; 48:769-778

9）水尻強志: 患者・利用者の移送と予防的リハビリテー ション対応. 大規模災害リハビリテーションマニュア ル（東日本大震災リハビリテーション支援関連 10 団体 『大規模災害リハビリテーション対応マニュアル』作成 ワーキンググループ 編). 医歯薬出版, 東京, 2012 ; pp 121-124

10) Jan $S$, Lurie $N$ : Disaster resilience and people with functional needs. N Engl J Med $2012 ; 367: 2272-2273$

11) Jangi $S$ : Facing uncertainty - dispatch from Beth Israel Medical Center, Manhattan. N Engl J Med 2012 ; 367 : 2267-2269

12）上田耕蔵: 東日本大震災, 医療と介護に何が起こったの か一震災関連死を減らすために. 萌文社, 東京, 2012

13）震災関連死死者数等について. Available from URL: http://www.reconstruction.go.jp/topics/main-cat2/subcat2-6/20140526131634.html (2015 年 1 月 12 日引用)

14）苅尾七臣 : 大災害時の心血管イベント発生のメカニズ ムとそのリスク管理. 心蔵 $2007 ; 39: 110-119$

15) Sokejima S, Nakatani Y, Kario K, Kayaba K, Minowa M, Kagamimori S : Seismic intensity and risk of cerebrovascular stroke : 1995 Hanshin-Awaji earthquake. Prehosp Disaster Med 2004 ; 19 : 297-306

16) Tsuchida M, Kawashiri M, Teramoto R, Tanaka M, Sakata K, Omi W, Okajima M, Takamura M, Ino H, Kita Y, Takegoshi T, Inaba H, Yamagishi M : Impact of severe earthquake on the occurrence of acute coronary syndrome and stroke in a rural area of Japan - experience from the Noto peninsula earthquake. Circ J 2009 ; 73 : 1243-1247

17) Nakagawa I, Nakamura K, Oyama M, Yamazaki O, Ishigami K, Tsuchiya Y, Yamamoto M : Long-term effects of the Niigata-Chuetsu earthquake in Japan on acute myocardial infarction mortality : an analysis of death certificate data. Heart 2009 ; 95 : 2009-2013

18) Sato M, Fujita S, Saito A, Ikeda Y, Kitazawa H, Takahashi M, Ishiguro J, Okabe M, Nakamura Y, Nagai T, Watanabe H, Kodama M, Aizawa Y : Increased incidence of transient left ventricular apical ballooning (so-called 'Takotsubo' cardiomyopathy) after the mid-Niigata Prefecture earthquake. Circ J 2006 ; 70 : 947-953

19) Aoki T, Fukumoto Y, Yasuda S, Sakata Y, Ito K, Takahashi J, Miyata S, Tsuji I, Shimokawa H : The Great East Japan Earthquake Disaster and cardiovascular diseases. Eur Heart J $2012 ; 33$ : 2796-2803

20）水尻強志, 金成建太郎, 木口らん, 稲垣倫子, 千葉明日香 : リハビリテーション処方を行った震災関連疾患の状況. Jpn J Rehabil Med $2012 ; 49$ : 324

21）大川弥生 : 生活不活発病一災害医療の新たな課題であ る「防げたはずの生活機能低下」.内科 $2012 ; 110$ : 1020-1025

22）成田徳雄 : 気仙沼地区における医療の現状とこれから. 宮城県医師会報 $2012 ; 803: 1068-1069$

23）石井 正 : 東日本大震災 石巻災害医療の全記録一「最 大被災地」を医療崩壊から救った医師の 7 力月. 講談社, 東京, 2012 